TITLE:

\title{
Intracarotid propofol test for speech and memory dominance in man(Abstract_要旨 )
}

\author{
AUTHOR(S): \\ Takayama, Motohiro
}

\section{CITATION:}

Takayama, Motohiro. Intracarotid propofol test for speech and memory dominance in man. 京都大学, 2006, 博士(医学)

ISSUE DATE:

2006-03-23

URL:

http://hdl.handle.net/2433/143819

RIGHT: 


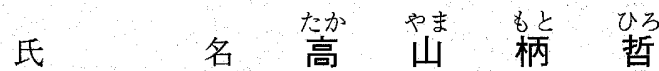

学位(専攻分野) 博士 士 (医 学)

学位記番号医 博 第 2939 号

学位授与の日付 平 成 18 年 3 月 23 日

学位授与の要件 学位 規則 第 4 条 第 1 項 該 当

研究科. 専攻医学研究科脳統御医科学系専攻

学位論文題目 Intracarotid Propofol test for speech and memory dominance in man.

(ヒトに扔ける言語機能ならびに記憶機能の優位側大脳半球評価のためのプ

ロポフォール内䅡動脈注入試験に関する研究）

論文調査委員教授福山秀直 教授河野憲二教授富樫かおり

論文内容 の 要旨

非侵襲的脳機能画像法の技術が進む一方で，一時的・直接的に脳機能を停止させることで言語機能と記憶機能の側方性を 同時に検討することが可能である Intracarotid amobarbital procedure（Wada test）は，脳神経外科の術前評価法の1つと して以前として重要な手法である。Wada testにおいては一過性に大脳半球の麻酔作用を得ることが必要不可欠であるが， これまで専ら用いられてきた Amobarbital が製造中止となったことを受け，代替薬剮としてPropofolを Wada testに用い Amobarbital と比較することでその有用性を検討した。

Propofol の用量はそれまでに海外から出されたいくつかの症例報告を参考にし, 濃度・薬液量ともに低く設定した。検 討症例は脳神経外科の術前評価としてWada test を施行した123例の内，右利きでかつ左右両側の注入薬液量が等しい67例 を対象とした。12例が Propofol で Wada test を施行し，対照として Amobarbital を使用したのは55例であった。検討事項 としては Propofol を直接内頚動脈に注入することで生じた合併反応とともに，言語機能と記憶機能の優位側大脳半球の同 定結果と, 薬剤注入後の徒手筋力テスト（MMT）に扔いて対側上肢が Grade0 から Grade3, Grade5 に回復するまでの時 間（T3/5，T5/5)，そして薬剤注入後に言語性反応，非言語性反応が初めて出現するまでの時間（Tverb，Tnon-verb）を 両群間で比較した。また 3 例(Propofol 群 2 例, Amobarbital 群 1 例) でWada test 施行中の背景脳波につきパワースペク トラム解析を施行し，薬剂注入によって出現する多型性徐波の時間的・空間的局在についても比較検討した。

Propofol を直接的に内䅡動脈に注入することで，一時的に同側の流涙としかめ面が数例で観察されたが，明らかな後遺 障害の残存は認めなかった。そして Propofolによって言語機能ならびに記憶機能の優位側大脳半球は，12例中それぞれ12 例，9例で同定され，対照の Amobarbital では55例中それぞれ52例，41例であり，両群に明らかな有意差は認めず，術前 評価としての Wada testに扔いて Propofol はその機能を果たし得るものと考えられた。また Propofol 群は Amobarbital 群と比してT3/5, T5/5 は共に短縮され，逆にTverb, Tnon-verb は共に延長していた。背景脳波活動のパワースペクト ラム解析においては, Propofol を用いた場合では Amobarbital と比較して多型性徐波はそのパワーが, 前者の場合時間的 に漸増しピークを経て急減するのに対し，後者の場合急増しピークを経て漸減することが観察された。また空間的には前者 の方が大脳半球上のやや広い局在に分布していた。

今回検討した症例では，内䅡動脈に直接 Propofol を注入することで明らかな後遺障害の出現・残存は認めなかった。ま た PropofolによるWada testでの言語機能ならびに記憶機能の優位側大脳半球の同定結果は十分に満足できるものであっ た。以上から Wada testに扔ける Amobarubital の代替薬剤としての Propofol の有用性が示唆された。ただ，その安全 性に関しては更なる症例の蓄積により検討がなされるべきであり，また種々のパラメーターにおける両群間の相違点が Wada test の Procedureに及ほす影響は，今後Wada testに扔いて新たな工夫発展の見込まれる可能性も今回同時に示唆さ れた。 
内頝動脈内アモバルビタールテスト（以下ワダ・テスト）は, 言語・記憶機能の優位側大脳半球判定に最も信頼できる術 前評価法である。本研究で大脳半球一過性麻酔の代替薬剂としてプロポフォールの有用性を検討した。

症例は右利きで両側に同用量注入した67例（プロポフォール群12例，対照アモバルビタール群55例）。内䅡動脈動注によ る副反応を検討し, 両群間で言語・記憶機能の優位側判定結果, 徒手筋力テストで対側上肢筋力がグレード0からグレード 3 ・ 5 に復す時間と言語性・非言語性反応の出現時間を比較。 3 例（プロポフォール群 2 例，対照群 1 例）では脳波解析も 施行。

後遺障害は全例で認めず，数例で一過性の笑いや流涙・歪顔等を観察。言語・記憶機能の優位側は, プロポフォール群で 12例中それぞれ12，9例で，対照群では55例中それぞれ52，41例で判定。プロポフォール群は対照群より筋力の回復時間は 共に短縮し，言語性・非言語性反応の出現時間は共に延長した。脳波解析で徐波パワーの時間的分布は，プロポフォールで 漸増した後に急減，対照では急增した後に漸廠した。空間的分布は前者で前頭にやや広かった。

本研究で薬剤の内䅡動脈動注で明らかな後遺障害は認めず，術前評価として言語・記憶機能の優位側は十分に判定された。 以上から, ワダ・テストでのプロポフォールの有用性が初めて示された。

以上の研究は「高次脳機能（言語・記憶機能）の優位側判定法」の解明に貢献し，「脳外科手術の術前評価法の発展」に 寄与するところが多い。

したがって，本論文は博士 (医学) の学位論文として価值あるものと認める。

なお，本学位授与申請者は，平成18年 1 月10日実施の論文内容とそれに関連した試問を受け，合格と認められたものであ る。 